\title{
The Limits of Agronomic Determinism: A Critique of Paige's Agrarian Revolution
}

\author{
MARGARET R. SOMERS AND WALTER L. GOLDFRANK
}

Harvard University and University of California, Santa Cruz

Social scientists left and right have long engaged in the project of identifying the conditions under which revolutionary, class-conscious social movements emerge. This project aims at prediction, in the hope of either promoting social revolutions or preventing them. Until quite recently both Marxist and liberal social scientists have focussed on "modern" urban social classes as the generators of revolution: the bourgeoisie, the intellectuals, the industrial proletarlat. But paradoxically, though Marx summarily dismissed the peasantry as so many "potatoes in a sack," and despite the generality of working-class social movements, the major revolutions of our time have been made largely by country people, to the extent that they were made by social movements at all. Thus two major issues take shape in the study of revolutions. One, how and why do peasants - allegedly "premodern" and conservative-defy the laws of social science and become revolutionary agents? What is it about rural social conditions that enabled them to dynamite the old order?' ${ }^{1}$ wo, what is the relationship between revolutionary social movements on the one hand, and revolutionary outcomes on the other? A movement entails the collective action of a class whose ideology may be described as more or less radical; a revolution entails the overhauling of a social structure. In this context, no matter how ideologically "revolutionary" a social movement may be, it is but one of the causal elements that converge to produce social revolution.

David Karen, Lauri Perman, Theda Skocpol, Charles Tilly, and Mark Traugott made helpful suggestions, but are not accountable for the outcome.

1 "Peasant" is of course a slippery term: many so-called peasants were and are artisanal and/or wage workers. "Rural workers" would be a more inclusive, perhaps less misleading notation. But it is not accidental that two of the most important macrosociological treatments of the modern trajectory in the last fifteen years make explicit reference to the countryside in their subtitles: Barrington Moore, Jr., Social Origins of Democracy and Dictatorship: Lord and Peasant in the Making of the Modern World (Boston: Beacon Press, 1966), and Immanuel Wallerstein, The Modern World-System: Agricultural Capitalism and the Emergence of the European World-Economy in the Sixteenth Century (New York: Academic Press, 1974).

0010-4175-79-7249-0594\$2.00

(C) Society for Comparative Study of Society and History 
Jeffery Paige's justly praised Agrarian Revolution ${ }^{2}$ contributes much to our understanding of these two questions, though not always self-consciously. In many ways, it serves as a prism for examining the difficulties involved in analyzing revolutionary agency, social movements, and revolutions. Paige provides the most rigorously theoretical redress so far to the neglect of the countryside in the study of revolutionary social movements by developing a careful argument about the form such movements take in their varied settings. But his accomplishment is uneven, and in the end, unsatisfying, with its curious amalgam of reductionist materialism and ahistorical positivism. Not only does he fail to explain agrarian revolutions, but by remaining within the traditional framework of "collective behavior" he falls short of adequately explaining his own true object of analysis, social movements themselves.

In the appraisal which follows, we undertake four tasks. First, we summarize the argument and the accomplishment of the book. Second, we discuss some problems with Paige's conception of social movements: definitional problems, the disappearing dialectic, and the unwarranted leap from movement to revolution. Third, we explore some difficulties with Paige's shifting units of analysis, his techno-economic determinism, and his (non)treatment of the state. Finally, we briefly bring these critical perspectives to bear on one of his case studies, Angola. Throughout we hope to suggest ways that future analyses can build upon the strengths of Agrarian Revolution, while avoiding its pitfalls.

\section{AGRARIAN REVOLUTION: THE ARGUMENT}

In his own words, Paige is trying to "determine the effect of the agricultural export economy on social movements of cultivators" (p. 3) in the underdeveloped world. Observing that what he characterizes as revolutionary social movements (either socialist or nationalist) have occurred in those countries dominated by one or more agricultural export sectors, he retraces the origins of those sectors to the creation of a global market in agricultural commodities around the turn of this century. These export sectors emerged as commercial enclaves amidst "traditional" subsistence economies. Thus emerged not only dual economies, but also new forms of class conflict: foreign owners of enterprises versus their wage laborers, new agrarian upper classes versus preexisting landed elites, newly commercialized landlords versus former tenants now working for wages or paying money rents.

Since he is above all concerned with explaining social movements, Paige argues that what is needed is a theory causally linking types of agricultural organization resulting from world commodity demand with specific types

\footnotetext{
${ }^{2}$ New York: Free Press, 1975. Agrarian Revolution shared the 1976 Sorokin Award for the best book in sociology.
} 
of agrarian movements. Rejecting Steward, Stinchcombe, and Wolf ${ }^{3}$ as primarily typological (linking patterns but not establishing causality), he states as his goal:

to propose a theory of rural class conflict which defines the recurring patterns of conflict in terms of interactions between economic and political behavior of cultivators and non-cultivators and predicts the circumstances under which these conflicts lead to cultivator social movements in general and agrarian revolution in particular. The fundamental causal variable in this theory is the relations of both cultivators and non-cultivators to the factors of agricultural production as indicated by their principal source of income (p. 10).

The first step of Paige's austere and elegant theorizing dichotomizes the income source for each of the two main rural classes, the cultivators (land or wages) and the noncultivators (land or capital). ${ }^{4}$ Using combinations of the income source of each class, he then builds a typology linking these income sources to the type of agricultural enterprise and finally to the type and character of social movement. The result looks like this:

CULTIVATORS

\begin{tabular}{ll}
\multicolumn{1}{c}{ Land } & \multicolumn{1}{c}{ Wages } \\
\cline { 2 - 2 } Land & \multicolumn{1}{c}{ COMMERCIAL } \\
HACIENDA & SHARECROPPING \\
& MIGRATORY LABOR \\
\cline { 2 - 2 } $\begin{array}{l}\text { REVOLT } \\
\text { (Agrarian) }\end{array}$ & $\begin{array}{l}\text { REVOLUTION } \\
\text { (Socialist) } \\
\text { (Nationalist) }\end{array}$ \\
\hline
\end{tabular}

NONCULTIVATORS

\begin{tabular}{|c|c|c|}
\hline \multirow{2}{*}{ Capital } & SMALL HOLDING ${ }^{5}$ & PLANTATION \\
\hline & $\begin{array}{l}\text { REFORM } \\
\text { (Commodity) }\end{array}$ & $\begin{array}{l}\text { REFORM } \\
\text { (Labor) }\end{array}$ \\
\hline
\end{tabular}

The second step of theory-building goes beyond these correlations to establish a causal model, linking each source-of-income combination with each social movement type. These linkages are expressed in terms of specific kinds of economic and political behavior-note, "behavior," instead of "action." The behaviors are at once a function of the particular income-source combination and the determinants of the social movement.

\footnotetext{
${ }^{3}$ Julian H. Steward et al., The People of Puerto Rico: A Study in Social Anthropology (Urbana: University of Illinois Press, 1956); Arthur L. Stinchcombe, "Agricultural Enterprise and Rural Class Relations," American Journal of Sociology 67 (September 1961), 165-76; Eric R. Wolf, Peasant Wars of the Twentieth Century (New York: Harper and Row, 1969).

${ }^{4}$ Paige makes it clear that these dichotomies represent to some degree points on a continuum of commercialized agriculture, yet yield in combination rather stable types (p. 336).

${ }^{5}$ Paige here draws upon Marx's classic analysis of small-holder dependence on brokers and bankers.
} 
Here Paige offers six hypotheses, three deriving from the situation of each class. Each hypothesis defines economic and hence political behavior in interactive terms and consequently leads to a predictable form of class conflict. This conflict behavior in turn produces the predicted type of social movement. For example, with respect to noncultivators:

An upper class drawing its income from the land is associated with a static agricultural product and therefore creates zero-sum conflict between cultivators and noncultivators. As a result compromise in economic conflicts is difficult. An upper class drawing its income from commercial or industrial capital can increase production through capital investment and therefore expand the sum of agricultural income to be shared with cultivators, and conflict is therefore non-zero sum. As a result compromise in economic conflicts is possible. This political difference is a direct result of the relatively greater importance of technology in agricultural systems controlled by industrial or commercial $\operatorname{classes}^{6}$ (p. 23).

This expresses one of the six hypothesis, one derived from the income source of the noncultivators yet presented in terms of economic and political interaction between the two classes. The crucial step for Paige is to mesh these causal hypotheses with the original four types. For example,

The combination of the upper and the lower agricultural classes drawing their income exclusively from land is characteristic of the commercial hacienda.... The nature of rural social movements in such commercial hacienda systems can be inferred from the combined effects of the political behavior of both upper and lower classes dependent on land. A landed upper class leads to intractable, zero-sum, political conflict over landed property and the control of the state. The upper class maintains itself through a system of special privileges based on the repression and disenfranchisement of most of the population. A cultivating class dependent on land is likely to be conservative, unable to organize collectively, and incapable of enforcing political solidarity. In short, it is politically incompetent... The form of social movement most common in the commercial hacienda system might be best described as an agrarian revolt-a short, intense movement aimed at seizing land but lacking long-run political objectives (pp. 40-43).

\footnotetext{
${ }^{6}$ The other two hypotheses regarding the noncultivators: (1) If they draw income from land they are economically weak, hence must rely on political restrictions on property, and hence focus conflict on control of property; if they draw income from capital they are strong enough to focus conflict on income rather than property distribution. (2) If they draw income from land they usually rely on servile labor, hence cannot permit the extension of political rights, hence politicizing labor conflicts; if they draw income from capital, they depend on free labor, hence can tolerate cultivator rights and thus confine labor conflicts to the economic realm. The hypotheses for the cultivators are: (1) The greater the importance of land as an income source, the more they avoid risk and resist revolutionary politics; the greater the importance of wages in cash or in kind, the more they will take risks and the more open they are to revolutionary ideas. (2) The greater the importance of land, the stronger the economic incentives to compete and the weaker the incentives to organize; the greater the importance of wages, economic competition is less and political organization more likely. (3) The greater the importance of land, the greater the structural isolation or dependence on elites and hence the weaker the pressures for political solidarity; the greater the importance of wages, the greater the cultivators' structural interdependence and hence the pressures for political solidarity. Paige, pp. $18-35$.
} 
Twice in his long theory chapter Paige uses comparisons within one of his broad types to establish the coherence of his model, and in these passages he is at his most persuasive. One compares the relatively conservative cotton sharecroppers of Egypt and the southern U.S.A. and the radical rice sharecroppers of China, Vietnam, Italy, the Philippines, and parts of India. The other, more extensive passage examines the apparently deviant case of the revolutionary movement of Malayan rubber plantation workers, explicating its differences from those of the more typically reformist labor movement among the tea plantation workers of Ceylon in terms of the contrasting forces and relations of production - the latter crop requiring more continuous labor inputs and allowing for technically based productivity increases. Even here, though, problems we shall discuss below emerge as untheorized parametric conditions: the declining competitiveness of Malayan rubber in the world market, and "the power vacuum created by the Japanese withdrawal" (p. 57). And the sad truth is that for all the revolutionary consciousness of the Malayan workers, their insurgency was crushed and no revolution occurred.

Paige then proceeds to test his hypotheses by two methods, statistical comparisons of 135 "export sectors" in 70 "developing nations" between 1948 and 1970, and case studies of three politically bounded territories, Peru, Angola, and Vietnam. In both methods, he correlates the type of agricultural organization with the "number of acts of rural protest" (p. 72), coded from secondary newspaper sources for the world analysis, and from primary newspaper sources for the case studies. In the latter, internal variations in agricultural organization and causal linkages with the modes of protest can be carefully explored.

In the world analysis, the theoretical typology is, grosso modo, borne out by the laboriously constructed and skillfully managed data set. The correlations between agricultural organization and types of social movement are quite strong. Further, the use of path analytic techniques reveals some interesting specifications consistent with the theory. For example, there is a tighter connection between strikes and plantation systems producing industrial as opposed to forest crops. But again, untheorized parametric conditions make an appearance: urban radical parties increase the likelihood of agrarian revolts in commercial hacienda systems; and without colonial regimes, migratory labor estates fail to give rise to revolutionary nationalism.

The case studies flesh out these rather skeletal correlations, moving from typology to causal theory by reintroducing (through not quite systematically) the six hypotheses about cultivators and noncultivators. Here we learn in some detail about the distinctive movements growing out of sugar, cotton, coffee, and wool production in Peru, coffee production in Angola, and rice cultivation in Vietnam. Although he misrepresents the generality 
and completeness of his explanatory scheme, Paige has definitively demonstrated the way in which particular forms of enterprise constrain class struggles toward particular types of movements: that if a radical movement emerges in a particular zone, then it will probably take a specifiable shape. If in the critical discussions to follow we focus on the shortcomings of Agrarian Revolution, we cannot emphasize too strongly our sense that it is nonetheless an impressive and valuable work.

\section{SOCIAL MOVEMENTS AS "DEPENDENT VARIABLES"}

Paige says that he wants to explain "cultivator social movements in general and agrarian revolution in particular" (p. 10). Three serious difficulties arise from this problematique. First, adopting the definition of social movement from the "collective behavior" tradition entails misconceiving both ends of the spectrum of political protest. Second, there is needless discontinuity between the relational theoretical model and the unidimensional dependent variable. Third, Paige puts revolution on a continuum with a "revolutionary" social movement, whose "success" is presumably the measure of revolution itself (this conceptual slide is evident in the above quote).

Paige explicitly follows the framework of Neil Smelser and Stanley Milgram? by considering as social movements collective behavior that occurs outside the established institutions of a society and involves participants who are united by some shared sense of intention or belief (p. 87). To identify the occurrence of social movement behavior, he uses observable actions clustered into what he calls "events." An event is any act or series of actions taking place on the same day or on successive days in the same export sector and the same (or a contiguous) first-order political division (p. 89), that is also collective, noninstitutional, and performed by a "solidary" group (p. 90) of cultivators (p. 91). The most important indicator for identifying the type of social movement is the ideology or goals of the movement: the specific demands of participants and/or the program of any political party with which they are affiliated (p. 94).

What is wrong here? First, as Paige himself admits, strikes-the prototypical action of plantation workers - are at best marginally noninstitutional. But so too are many instances of armed rebellion in Latin America, where it has been a traditional tactic of aggrieved rural groups to make a brief uprising in order to embarrass a local official or to call attention to a problem; such uprisings are often instigated by rival politicians. Second, in some cases Paige identifies an outside party with the very meaning of an

\footnotetext{
${ }^{7}$ Neil Smelser, Theory of Collective Behavior (New York: Free Press, 1962); Stanley Milgram and Hans Toch, "Collective Behavior: Crowds and Social Movements," in L. Gardner and E. Aronson, eds., The Handbook of Social Psychology, Vol. IV (Reading, Mass.: Addison-Wesley, 1969).
} 
indigenous movement (other cases, such as regional secession movements, are excluded from the analysis). Bringing in an external factor here entails the creation of phenomena, meant to be derived from the theory, that the theory itself cannot explain. In this way, he conflates the ideology of a self-conscious party, more often than not one with a national scope, with the internal character of a movement supposedly limited to the export sector alone.

Third, even without the political party association, the reliance on ideology to characterize social movements causes problems. Here Paige keeps the faith with most social movement theorists, who typically assume that for a movement to be revolutionary it must have revolutionary goals. For example, he discusses the land invasions of Peru's commercial haciendas as mere short-term revolts. To be revolutionary, the participants would have to have expressed conscious aspirations to seize the state, transform rural class relations, or both. Yet land seizures in Mexico in 1913 and Russia in 1917, as well as lesser revolts in France in 1789, though carried out by predominantly nonrevolutionary peasants (as defined by their ideology), transformed political revolutions at the top into social revolutions from below.

Finally, it seems unwise to collapse events-the indicators of the dependent variable - into the definition of a social movement itself. On the one hand, to do so confuses the research technique with the substantive phenomenon. On the other hand, despite the odd inclusion of violence initiated by "social control forces" (p. 90) as social movement events, this insures that the definition of social movements will be limited to the cultivators alone.

This brings us to the second problem with social movements as "dependent variables": the discontinuity between the theoretical model and the explanandum. What makes Paige's theory so interesting is the interaction built into it. The model specifies a relational causality in which patterns of conflict are defined between antagonistic classes with respect both to economic/political action and to the combinations of income source for cultivators and noncultivators. Yet the dependent variable, what this interactive theory is meant to explain, lacks the relational quality intrinsic to the "independent variable" of income source combination: it is the movement of cultivators alone that is to be explained. Social movements are characterized not as relational activities in which both classes dialectically affect one another, but as the isolated behavior of one class alone. Methodologically, this discontinuity makes possible the sort of quantification Paige carries out. Substantively, it explains two things.

First, the non-relational conception of social movements explains Paige's focus on ideologies and parties as identifying movement types. Ideology and party attachment represent not the structural interaction of two contending classes, but one aspect of one side. An alternative concep- 
tion of the character of a social movement would rest on the potential for revolutionary action of which the cultivating class is capable, regardless of ideology. This would involve maintaining both classes in the characterization, since revolutionary capability is a function not only of the workers' will to act but also of the opportunities for action generated by the upper classes. To use the French example, the capability of the peasantry derived both from the rural communal structure and from the economic and political power of the landed class vis-à-vis both the peasants and the state.

The second issue illuminated by seeing that Paige shifts from a relational theory to a unidimensional dependent variable is his identification of a revolution with a revolutionary social movement. This of course brings us to the third problem noted at the outset of this section. He wants to explain "cultivator social movements in general, and agrarian revolution in particular" (p. 10); this formulation assumes that agrarian revolution is one (if not the) logical outcome (the particular) of a certain sort of cultivator social movement. By positing the activity of the cultivators alone as constitutive of the social movement, Paige slips into the trap of most social movement theorists: a revolution is like a revolutionary movement, only a little more so.

Here the problem may be definitional. Paige may merely be arguing that a revolutionary agrarian movement (defined by ideology and/or party affiliation) is a "revolution" in and of itself. Yet by not making this distinction explicit, he collapses movement and revolution together, which would have been impossible had he used the Philippines instead of Vietnam as his case study of decentralized rice sharecropping.

There is another way in which Paige traps himself. By characterizing revolutionary social movements as entailing the demand to seize the state and transform politics, he suggests that a revolution must include change from above as well as from below; yet demands and actions are confused with actual political transformation by his extrapolation from lower class social movements to revolution. "It is [the] combination of thoroughgoing structural transformation, and massive class upheavals that sets social revolutions apart from coups, rebellions, and even political revolutions and national independence movements." ${ }^{8}$ Had Paige stuck with his relational model, he would have been led to pursue the activities and repressive capabilities of the upper classes, and he would have had to bring the structure of the state - including most importantly its relation to those upper classes - to bear on the very characterization of the dependent variable. ${ }^{9} \mathrm{Had}$ he come this far, he might well have arrived at a conception

\footnotetext{
${ }^{8}$ Theda Skocpol, "France, Russia, China: A Structural Analysis of Social Revolutions," Comparative Studies in Society and History 18: 2 (April 1976), 175-210.

${ }^{9}$ For case studies attempting this, see Walter L. Goldfrank, "World System, State Structure and the Onset of the Mexican Revolution," Politics and Society V, 4 (Fall 1975), pp. 417-39,
} 
of revolution allowing him to derive revolutionary potential from the land invasions in Peru (if combined with different forces from outside the Sierra), and he might not have made the mistake of implying that the UPA (which split in 1964 into what would become Unita and the FNLA) would be the victorious party in Angola.

These problems of prediction are the most salient result of generating a definitional continuum from a revolutionary social movement to an actual revolution. When revolutions are inferred from social movements, historical factors appear in ad hoc fashion rather than theoretically. Hence, this approach, in its attempt at theoretical generality, is ironically characterized by unsystematic and erratic reliance on the grabbag of history, or, to put it another way, by an unfortunate gap between history and theory.

THE UNIT OF ANALYSIS: AGRONOMIC DETERMINISM, THE STATE, AND THE WORLD-SYSTEM

Agrarian Revolution has problems with more than its "social movement" conception; it has problems with where revolutions occur, and why. Paige's theory is one of rural class conflict, of how different forms of commercial agricultural enterprise give rise to different types of social movement. His world comparative analysis makes the first shift: from rural class conflict in general to "export sectors" which the rise of the world market made possible, and limited to the period from 1948 to 1970 . In this part of the book, then, regions, and not politically bounded territories, are the unit of analysis; often there are several such units within a given political entity. Such a procedure permits him to make the striking statistical findings relating types of movement to types of enterprise and illuminates the patterns of political conflict in the four regions of the Peruvian case study.

But in Vietnam and Angola, where revolutions actually happened or are in process (the final victory of the revolutionary forces of course occurred after the completion of the book and the transformations continue), his unit of analysis shifts somewhat from the region to the national territory. This shift concedes two of our earlier points: that revolutions occur within politically bounded territories since they necessarily require national political transformation, and that Paige's reliance on parties to define a revolutionary movement is internally inconsistent, since the revolutionary parties in both Vietnam and Angola arose not from the export sectors but from elsewhere.

And then there is the world-system as a unit of analysis and source of variation itself. Curiously, this theory, premised on the existence of world commodity markets, has nothing to say about the effects of price fluctuations or about the demand-induced conversion of lands formerly devoted and Theda R. Skocpol, States and Social Revolution: A Comparative Analysis of France. Russia, and China (Cambridge: Cambridge University Press, 1979). 
to subsistence crops, even though at various points the case studies bring in these phenomena. Not so curiously, but equally unfortunately, Paige's theory has nothing to say about the political dimensions of the worldsystem, despite the importance of imperial allies (in various military, economic, and technical guises) to peripheral upper classes. The Vietnamese case is particularly striking, as the logic of world power, to borrow the title of Franz Schurmann's account of the USA-USSR-China triangle, was superimposed on a rural social movement.

To probe further into this "unit of analysis" problem we shall focus on Paige's techo-economic reductionism at the regional level, and save more extensive discussion of state structure and world-system for the ensuing section on Angola. In considering techno-economic determinism, it will help to examine briefly one of the hypothesized causal patterns, that connecting migratory labor estates with revolutionary nationalist movements. These movements are said to derive from the combination of an upper class drawing its income from land (not capital) and a cultivating class drawing its income from wages (not land). An upper class drawing its income from (a fixed amount of) land is associated with a static agricultural product and therefore finds itself in zero-sum conflict with cultivators, conflict in which compromise is difficult and hence repression or revolution are the only possible outcomes. Let us examine the problems of the formulation with respect to each class in turn.

Though Paige derives his categories of cultivator and noncultivator from a Marxian analysis of class, in many ways he is more a materialist than a Marxist. By making the type of agricultural enterprise, and hence the source of income the "exogenous independent variable not explained by other variables in the model" (p. 334), he loads the causal weight heavily on the forces of production rather than the relations of production. He thus gives theoretical priority to economic factors which may have been historically determined by previous class and political struggles. For Paige, the nature of class struggle - "economic and political conflict behavior"-is derived from the prime mover of income source alone. This causal ordering as if by dictum of the Third Internationa $1^{10}$ overly reduces political factors at the level of the enterprise and region as well as giving no theoretical status at all to national politics.

Hence we are left with a techno-economic determination of the level of productivity, in which economic resources then determine the zero-sum character of upper-class political action. An alternative model of technology would posit it as the result of the intersection of forces and relations of production, the outcome of competition and class struggle. In Paige's view, economic resources and ultimately the level of productivity explain the upper class's granting or withholding concessions to the workers. On

${ }^{10} \mathrm{Cr}$. Paige's repeated references to the Peruvian haciendas as "feudal." 
this basis alone, if they cannot give concessions-as in the hypothesis above of an upper class dependent on land-and if the direct producers receive wages, then the upper class will face a revolutionary nationalist movement from below.

But the upper classes have other resources besides economic ones, namely organizational and political ones. They may be tightly or loosely organized as a class, and they may be well or poorly connected at the level of the national state or other politically bounded territory. (Again, these untheorized factors emerge in the case study of Peru.) In fact, such organization and connections may causally precede the determination of the source of income of the noncultivators and even the degree to which other than local markets penetrate a particular region. And typically via the state apparatus, agrarian elites may be able to command resources for their struggle from other states. To take the example closest to home, the Cuban revolution led the U.S. government and its Latin American allies to carry out new programs of economic assistance and counterinsurgency, programs which altered the balance of forces in much of the Latin American countryside.

Paige fares little better in his discussion of cultivator behavior, although descriptively he focuses on the important factor of the peasants' organizational capacity in assessing their level of structural autonomy. His hypothesis is that the greater the importance of wages, the greater the structural interdependence of cultivators and the stronger the pressure for political solidarity. Structural ties to the upper class versus cultivator autonomy is crucial in asking under what conditions workers can rebel. But Paige's theory reduces this phenomenon to economics alone, as all of the complex dimensions of class formation and consciousness are conflated into a function of income source.

Again, organization and politics can provide an enriched alternative perspective. Tactical space and the potential to rebel might have brought about sufficient levels of rural class struggle to win wages in the first place. On the other hand, the organization of the rural workers is generally related to the connectedness of the upper class to the state. A weak dominant class is more likely than a strong one to generate an autonomous peasant community, And though it is less prominent than for the upper classes, forces outside the state boundaries can make a difference in the outcome of rural class struggles (sanctuary, arms, deterrence of upper class allies). According to the Vietnamese Communists, the following factors made up the balance of forces: organizational, moral, technological, spatial, economic, and external aid. "In the study of revolution, practice may have as much to teach theory as research.

11 Jeffrey Race, War Comes to Long An: Revolutionary Conflict in a Vietnamese Province (Berkeley: University of California Press, 1972), p. 144. 


\section{ANGOLA: THE CASE CONFUTES THE MODEL}

To ground our critique of Paige's theoretical argument, we shall briefly explore his case study of Angola. This case not only illustrates many of the problems discussed above, but also provides evidence to contradict the theory.

The Angolan coffee region is a case of an upper class dependent on land and a lower class deriving its income from wages-typical of both sharecropping and migratory labor estate systems. According to Paige's hypothesis, this land/wage combination should produce a revolutionary nationalist movement (sharecropping tends to result in revolutionary socialist movements). Let us trace the causal path between the incomesource combination and agrarian revolution. Like all export sectors, Angola's coffee economy was initially formed in response to rising world demand. In this case, Angola was already a Portuguese colony, one deep in economic stagnation. The coffee boom of the 1950s ended this stagnation, as foreign settlers formed a new landed elite. This is characteristic of the migratory labor estate and in contradistinction to the sharecropping systems, in which the preexisting rural upper class maintains its role in the newly intensified export economy. In both cases, however, the upper class is economically weak, since it cannot rely on productivity increases and economies of scale, and therefore has few economic resources with which to secure power as a class. Consequently, it tends to rely on legal and extralegal force to secure land and labor, adopt an intransigent attitude toward labor organizations, and is unable to make concessions to workers (p. 67).

The workers in the migratory estate system, however, remain in part dependent on subsistence production and their involvement in tribal or village social structures, while being paid for their estate labor in wages. Since they return to their own villages, the migrant laborers do not tend to form group solidarity on the basis of work-group interdependence. Paige suggests that this pattern of returning home for subsistence, as well as the high turnover in the work groups, not only makes class-based organization impossible in migratory situations, but also tends to create a situation in which workers are apathetic, divided, and disorganized. Yet, the conditions are present for a nationalist movement, because of the structural interdependence of the indigenous elite, the traditional community, and the migrant workers, all united in a common hatred of the colonizer.

So what pushes these "apathetic" workers into any kind of revolutionary movement at all? For this to occur, there must be "the introduction of political organization from outside the workers' community. The workers themselves are too divided to provide the coherent political organization necessary for armed insurrection" (p. 68). Describing Kenya, Paige says that revolutionary nationalism resulted when a well-organized political party 
faced an inflexible settler elite dependent on force rather than economic power, uniting under nationalist ideology the diverse interests of subsistence cultivators, tribal leaders and migratory wage laborers (p. 69).

In his account of Angola, Paige tells a similar story. The Angolan migrant workers maintained very strong ties to their own coherent tribal communities. "The tribal social structure, while considerably weakened, remained a viable source of economic opportunities and political authority for Africans cut off from white society" (p. 224). Estate work reinforced this pattern: the foremen were conscious of tribe and lineage relations among the workers and generally permitted kinsmen to work together in the same gangs. This policy reinforced the local and communal interests of the workers and tended to discourage broader, class-based worker organization (p. 251). And, ultimately, a revolutionary nationalist movement emerged, for which the indigenous political apparatus provided important components of the organizational framework. The great uprising of 1961 was suppressed (at a cost of 30,000 to 40,000 African lives), but guerrilla activity continued into the 1970 s.

Yet Paige correctly asserts that the generation of this movement was dependent on the penetration of the area by a revolutionary party, in this case the UPA, which grew up outside Angola among exiles in Zaire (then the Congo). The UPA was a rural communal party which resonated to the persistence of tribal social institutions and which, according to Paige, had little difficulty in winning the loyalties of the people over the more classbased and assimilationist MPLA. There is a striking incongruity between this assertion and the progress of the story as we now know it: the MPLA, not Unita and/or the FNLA, emerged as the victorious party in what may well prove to be the successful Angolan revolution. That it is a revolution, not simply a social movement, advises us to seek explanations in other factors in addition to those economic forms constraining toward a particular type of social movement in a particular region.

Paige describes the political character of much of the Angolan interior from about 1920 to 1950 as more like a network of military outposts of the Portuguese occupying army than like a working political system. Below this central administrative weakness, however, were strong units of locally autonomous tribal kingdoms and political structures. Portuguese weakness in the world-system was reflected in the stagnation of its colony and the thinness of colonial control; obversely, that several kingdoms had so long remained external to the capitalist world-economy (rather than being incorporated as peripheral zones) ${ }^{12}$ left remnants of the traditional political

${ }^{12} \mathrm{Cf}$. Wallerstein's comparison of sixteenth-century Russia (external) and Poland (peripheral) in Modern World-System. Ch. 6; and Paul Lubeck's comparison of nineteenth-cent ury Nigeria's Northern (external) and Southern (peripheral) regions, "Islam and Resistance in Northern Nigeria," in Walter L. Goldfrank, ed., The World-System of Capitalism: Past and Present (Beverly Hills: Sage Publications, 1979). 
apparatus which could provide "the framework for the nationalist revolt of the 1960s" (p. 217).

From this description it is clear that the political balance of forces affected the timing and nature of the penetration of the world market. Marked by "centers of political organization and resistance" (p. 211), the colony required continual military operations for pacification, making it unattractive for sustained investment and immigration. Indeed, when the coffee export economy took off in 1950, the boom lasted only ten years, because of the collapse of world coffee prices and the large-scale nationalist uprisings of $1960-61$.

In addition, the account of the political kingdoms gives evidence that the depth of market penetration was also a function of indigenous Angolan political strength. Only certain areas of the colony were beaten into assimilationist political submission, while others remained hostile up through 1961. Finally, even the enterprise type - the migratory labor estate-was to a large degree determined by the strength of tribal political organization, as the indigenous elite were not easily siphoned off into the upper class of an export region as is the case in sharecropping systems. Paige himself points out that small holdings were more efficient enterprises for growing lowgrade robusta coffee. But the small holders were squeezed out by the use of colonial force, as lands were seized and defended and labor was virtually conscripted - scarcely the usual "wage" situation. "The dominance of the elite . . clearly [did] not depend on economies of scale or on control of export or processing, but on the legal and political advantages of European settlers under colonial rule" (p. 230). Thus rather than being an exogenous independent variable, the agricultural organization should be seen as the vector sum of world demand for coffee, a relatively weak colonial power, and a relatively strong indigenous political system. None of this is suggested in the theoretical formulation, whereas the careful descriptions contradict the techno-economic reductionism of the causal model.

Paige's theory further hypothesizes that the determination of a revolutionary nationalist movement is based on the wage-dependence of cultivators faced with an intransigent, weak noncultivating class dependent on land in the context of such migratory labor estates. These economic factors create the conditions; a revolutionary party actually triggers the movement.

But again, the descriptions belie the model. In contrasting Angola with Peru, he points out that "differences in both the social organization of coffee production and the nature of the political system between the two countries ... created the preconditions for a class-based agrarian movement in Cuzco but for a communal, revolutionary nationalist movement in Angola" (p. 212, italics added). The noncultivators were able to call upon a colonial army to put down the revolt, an army supplied by Portugal's more 
powerful NATO allies. The cultivators derived their strength less from the kind of organization attendant upon "wage labor" than from the continuing viability of the tribal political and social structures. The theoretical neglect of political organization (at the local, national, and world-system levels) stands in stark contrast to the richly textured account of historical process.

Another stricture arises from Paige's analysis of the developing nationalist movement. He shows (p. 269) that the movement was strongest in the very districts where substantial numbers of indigenous small-holding coffee producers were expropriated so that settler estates could be installed. This is not the first time in history that displaced peasant producers played a significant part in generating social movements and making revolution, yet there is no place for them in Paige's theory except as a virtual afterthought in the conclusion (pp. 346, 366). Why? Because in spite of going beyond typology by drawing out valid causal connections between types of agricultural organization and types of social movement, Paige has imposed a static conceptualization conducive to quantifiable measurements on an historically constituted and reconstituted reality.

Finally, though an explanation of the MPLA's ultimate victory in Angola cannot be pursued here, the impact of Paige's assumption of Unita-FNLA ascendance should not be lost. For it is a clear instance of the fallacy of deriving a revolutionary outcome from an ideologically defined "revolutionary" social movement. The MPLA's hold on the sentiments of many rural Angolans may be questionable, as seems at this writing to be the case. But its grasp on state power is fairly secure, in no small part because of the world political-economic shifts attendant on Great Britain's entrance into the European Economic Community, the defeat of the United States in Vietnam, and Cuban aid, as well as the strategic location of MPLA support. Thus the Angolan case, in all of its complexity, reveals the weakness of "social movement" approaches to revolution.

Most striking to us is the discontinuity between theory and history in Agrarian Revolution, though others may complain about the absence of intervening social-psychological mechanisms between structural conditions and social movements. ${ }^{13}$ Concerned above all with theory construction, Paige provides abundant data indicating that historical events and structural arrangements not accounted for in the theoretical propositions are the necessary conditions for an actual revolution. Extrapolating revolutions from social movements, as we saw in the Angolan case, is one source

${ }^{13}$ One such mechanism is that proposed by James Scott in his discussion of rice cultivators in Southeast Asia, their subsistence ethic and "safety first" mentality: The Moral Economy of the Peasant: Rebellion and Subsistence in Southeast A sia (New Haven: Yale University Press, 1976). Oddly enough for a materialist, Paige never considers the possibility that the production of basic food grains differs in important ways from that of other commericial crops. 
458 MARGARET R. SOMERS AND WALTER L. GOLDFRANK

of a long-losing record of predictions. For such prediction to approach reality more closely, political structures and world political-economic relations must be theoretically incorporated along with enterprise forms and class conflict, not smuggled into descriptive accounts as ad hoc historical contingencies. 